\title{
Low genetic diversity in the Endangered Crested Ibis Nipponia nippon and implications for conservation
}

\author{
BEI ZHANG, SHENG-GUO FANG and YONG-MEI XI
}

\begin{abstract}
Summary
Crested Ibis Nipponia nippon is an Endangered species that has experienced a severe but short-lived population bottleneck in recent years. Only one wild population and two captive populations exist in China today, all of which were probably initiated from two breeding pairs rediscovered in 1981. This paper represents the first study of the genetic diversity of Crested Ibis by analysing sequence variation of a fragment spanning domains II and III of the mitochondrial DNA (mtDNA) control region of both wild and captive populations. Two haplotypes were identified in both wild and captive populations, and the captive population had a bias towards haplotype 1 . The species as a whole demonstrated an extremely low level of genetic diversity, with a haplotype diversity and nucleotide diversity of $0.386 \pm 0.074$ and $0.069 \% \pm 0.013 \%$, respectively. Despite the rapid increase in numbers of birds under intensive management, the paucity of genetic diversity remains a real threat to the species. The mtDNA control region variations detected in the present study could provide significant information additional to the studbook data of Crested Ibis; therefore we suggest that special attention be paid to individuals with haplotype 2 when considering captive breeding management. Overall, great care should be taken in the selection of reintroduction sites for this rare bird, as species with low genetic diversity are thought to be more limited in their ability to tolerate a wide range of environmental extremes and diseases.
\end{abstract}

\section{Introduction}

Crested Ibis Nipponia nippon is a good example of a species that has suffered a severe but short-lived population bottleneck. It is regarded as "Endangered" in the 2000 IUCN Red List of Threatened Species (http://www.redlist.org), and is listed as an endangered species on the State Key Protected Wildlife List of P. R. China (Wang 1998). Historically, the species was widespread throughout the Russian Far East, Korea and Japan, to central China (Yamashina 1975). Habitat loss, hunting and environmental pollution are believed to be the dominant factors that have brought about its catastrophic decline since the late nineteenth century. Wild populations were almost extinct in Japan, Korea, China and the Russian Far East by the late 1970s (Yamashina and Nakanishi 1983). In Japan, Crested Ibis is a symbol of public concern for endangered species. However, only a single Crested Ibis survived in Japan, until a pair loaned by the Chinese Government to the Japanese Emperor was successfully bred at the Sado Ibis Conservation Centre in 1999 (Xi and Fujihara 2000a,b). In China, the rediscovery of seven wild Crested Ibis in Yangxian, Shaanxi Province in 1981, including 
four adults and three nestlings, renewed hope for the species (Liu 1981). The Shaanxi Crested Ibis Natural Reserve was established in 1990, and this magnificent bird has since been the focus of intensive conservation effort. As a result, this population, the only wild population in the world, has been gradually recovering.

Six fledglings were taken from the wild to initiate a captive population in Beijing Zoo, and the first successful breeding was achieved there in 1989 (Li 1991). Another captive rearing and breeding programme began at the Shaanxi Crested Ibis Breeding Centre in 1990 with the rescue of sick or injured chicks and the collection of some of the eggs deserted by parental birds in the wild (Xi et al. 2002). By 2002, the total number of Crested Ibis, including the wild and captive populations in China, had recovered to nearly 300 individuals, and has continued to increase since (Ding and Liu 2002).

In recent years, modern molecular genetic markers and analyses have helped in resolving the genetic backgrounds of many threatened species, with clear implications for their conservation (Avise 1994, Vrijenhoek 1998, Sunnucks 2000). Mitochondrial DNA (mtDNA) sequencing has often revealed huge amounts of genetic variability within and among conspecific populations (Avise 1994). The advantage of this method over other techniques is that it can be done following non-invasive sampling, which is of great importance to endangered species. Therefore, mtDNA, because of its high mutation rate, has been widely applied in population genetics (Glenn et al. 1999, Matthee and Robinson 1999, Grunwald et al. 2002) and conservation biology of endangered animals (Kretzmann et al. 1997, Pestano et al. 2000, Balakrishnan et al. 2003).

The importance of genetic diversity lies with both short-term effects, i.e. the maintenance of reproductive fitness, and long-term effects, i.e. the maintenance of adaptive evolutionary potential (Frankham et al. 2002). As the population of Crested Ibis has increased, however, reports have begun to accumulate of reduced reproductive fitness (e.g. the presence of easily broken eggs, abnormal chicks, low fertility and low productivity) (Xi et al. 2001). This might be the first sign of low genetic diversity, and it is feared it may threaten the long-term survival of this species. Therefore, for the first time, we examined the genetic diversity of Crested Ibis by a detailed analysis of the mtDNA control region sequences from both wild and captive populations. In this study we aimed to: (i) reveal the status of its genetic diversity after such a severe but short-lived population bottleneck; and (ii) provide feasible strategies for further conservation of this species.

\section{Materials and methods}

\section{DNA extraction, amplification and sequencing}

In total, 1o samples were collected from wild birds at the Shaanxi Crested Ibis Natural Reserve and 26 samples were collected from captive birds in the Shaanxi Crested Ibis Breeding Centre, Yangxian, Shaanxi (Table 1). Total genomic DNA was isolated and purified by proteinase $\mathrm{K}$ digestion and phenol/chloroform extraction following standard procedures (Sambrook et al. 1989). First we used a pair of degenerate primers developed by Sorenson et al. (1999) to amplify a 
Table 1 . Summary information on the samples of Crested Ibis used.

\begin{tabular}{lcll}
\hline Population (Sampling site) & No. of individuals & Type & Sampling year \\
\hline Wild population & 1 & Feather & 1990 \\
(Shaanxi Crested Ibis & 1 & Muscle & 1990 \\
Natural Reserve) & 6 & Blood & 1993 \\
& 1 & Muscle & 1993 \\
& 1 & Feather & 1997 \\
\hline Captive population & 3 & Blood & 1995 \\
(Shaanxi Crested Ibis & 5 & Muscle & 1997 \\
Breeding Centre) & 4 & Feather & 1997 \\
& 3 & Blood & 2000 \\
& 10 & Muscle & 2000 \\
& 1 & Feather & 2000 \\
\hline
\end{tabular}

portion of the mtDNA: L537 (5' CCT CTG GTT CCT CGG TCA G 3') and H1251 ( $5^{\prime}$ TCT TGG CAT CTT CAG TGC CRT GC $3^{\prime}$ ). Then an agarose gel electrophoresis was run and the band of interest was eluted by UNIQ-5 Column DNA Gel extraction kit (Sangon, China). The purified DNA fragment was ligated into a pMD 18-T vector (TaKaRa, China), and was sequenced following the extensiondideoxy-chain termination method with universal primers $\left(\mathrm{M}_{13}+\mathrm{M}_{13}-\right)$ and the BigDye terminator cycle sequencing kit (Perkin Elmer) according to the manufacturer's instructions, and analysed on an ABI PRISM 377-96 DNA sequencer. Based on the sequence obtained, we designed a pair of primers for amplification of a portion of Crested Ibis mtDNA: CIDL (5' CTT GGT TAA TCC CTT CTT CT 3') and CIDH (5' GGT TGT AAG CTA CAA GGA CT 3'). A minimum DNA fragment of 648 base pairs (bp), comprising a part of the mtDNA control region and $19 \mathrm{bp}$ of the flanking tRNA ${ }^{\text {Phe }}$ genes, was obtained. Polymerase chain reaction (PCR) amplification was carried out on a PTC-20o Peltier Thermal Cycler. A $50 \mu \mathrm{l}$ reaction was performed using $50 \mathrm{ng}$ of template DNA, $5 \mu$ of $10 \times$ reaction buffer, $1.5 \mathrm{mM} \mathrm{MgCl}_{2}, 150 \mu \mathrm{M}$ of each $\mathrm{dNTP}, 0.25 \mu \mathrm{M}$ of each primer and 1.5 units of TaKaRa Ex Taq DNA Polymerase (TaKaRa, China). The thermal cycling profile was as follows: an initial hot-start at $95^{\circ} \mathrm{C}$ for $4 \mathrm{~min}$; 30 amplification cycles of denaturation at $94^{\circ} \mathrm{C}$ for $1 \mathrm{~min}$, annealing at $58^{\circ} \mathrm{C}$ for $\mathrm{I}$ min and extension at $72^{\circ} \mathrm{C}$ for $1 \mathrm{~min}$; followed by a final incubation at $72^{\circ} \mathrm{C}$ for 10 min to ensure complete extension of the PCR products. The PCR amplification products were separated and eluted by agarose gel electrophoresis and UNIQ-5 Column DNA Gel extraction kit (Sangon, China), and were ligated into a pMD 18-T vector (TaKaRa, China). The products were then sequenced and analysed following the same methods as before.

\section{Data analysis}

Sequences were aligned using the Clustal X program (Thompson et al. 1997). The $3^{\prime}$ ends of the control region were variable, due to tandem repeats, so they had to be removed in the alignments. Initial sequence comparisons and measures of variation were performed using MEGA version 2.1 (Kumar et al. 2001). Two standard measures of genetic diversity $-h$, the haplotype diversity, and $\pi$, the 
nucleotide diversity - were calculated using DNA-SP software version 3.51 (Rozas and Rozas 1999). Tajima's tests (1989) of neutrality of mutations were applied to both sets of sequences by DNA-SP version 3.51.

\section{Results}

A minimum of 648 bp sequence was obtained from the PCR amplification, and intra-individual length heteroplasmy, i.e. the occurrence of different size variants within one individual, was detected. This was due to the different copies of the $\left(\mathrm{CA}_{3} \mathrm{CA}_{2} \mathrm{CA}_{3}\right)$ tandem repeats at the $3^{\prime}$ end, and the more complicated repeat complex $\left(\mathrm{CA}_{3} \mathrm{CA}_{2} \mathrm{CA}_{3}\right)_{4} \mathrm{CA}_{3} \mathrm{CGACA}_{3}\left(\mathrm{CA}_{3} \mathrm{CA}_{2} \mathrm{CA}_{3}\right)_{2} \mathrm{CGA}_{2} \mathrm{CA}_{2} \mathrm{CA}_{3}\left(\mathrm{CA}_{3} \mathrm{CA}_{2} \mathrm{CA}_{3}\right)_{3}$ occurred in 10 individuals.

We used the $563 \mathrm{bp}$ fragment omitting the tandem repeats for alignment. Among the 36 individuals analysed in this study, the only variable site $(0.178 \%$ of the entire sequence) was a transition at position 24, which defined two haplotypes. Both the haplotypes were shared between the wild and the captive population. Haplotype 1 ("T" in position 24) was distributed in six wild and 20 captive individuals, while haplotype 2 ("C" in position 24) was found in four wild and six captive individuals. Genetic diversity measures were estimated for both populations and total individuals (Table 2), and the haplotype diversity and nucleotide diversity of the total individuals were only $0.386 \pm 0.074$ and $0.069 \% \pm 0.013 \%$, respectively. The hypothesis that observed mutations were selectively neutral could not be rejected for either wild or captive population by Tajima's (1989) tests (Table 2).

\section{Discussion}

\section{Control region characteristics}

There is no precise definition of the three control region domains in the existing literature. However, we delineated control region domain II and domain III based on the conserved sequences described in previous studies (Brown et al. 1986, Ruokonen and Kvist 2002). The fragment gave $317 \mathrm{bp}$ of domain II, and length heteroplasmy due to the repeat region was observed in domain III, which made it impossible to assign a specific size to the control region in Crested Ibis. Such a repeat region, with a low sequence complexity dominated by $\mathrm{Cs}$ and As in the L-strand, has been observed in several other species in the Order

Table 2. Measures of mitochondrial DNA diversity observed in the two populations of Crested Ibis.

\begin{tabular}{|c|c|c|c|c|c|c|c|c|}
\hline Population & $\mathrm{N}$ & $\mathrm{N}_{\text {hap }}$ & $\mathrm{N}_{\mathrm{h} 1}$ & $\mathrm{~N}_{\mathrm{h} 2}$ & $\mathrm{~S}$ & $h$ & $\pi^{*}($ in $\%)$ & Tajima's D \\
\hline Wild & 10 & 2 & 6 & 4 & 1 & $0.533 \pm 0.095$ & $0.095 \pm 0.017$ & $1.30268^{+}$ \\
\hline Captive & 26 & 2 & 20 & 6 & 1 & $0.369 \pm 0.091$ & $0.066 \pm 0.016$ & $0.66896^{+}$ \\
\hline Total & 36 & 2 & 26 & 10 & 1 & $0.413 \pm 0.068$ & $0.073 \pm 0.012$ & $1.04744^{+}$ \\
\hline
\end{tabular}

$\mathrm{N}$, number of individuals; $\mathrm{N}_{\text {hap }}$, number of haplotypes; $\mathrm{N}_{\mathrm{h} 1}$, number of haplotype 1 ; $\mathrm{N}_{\mathrm{h} 2}$, number of haplotype 2; S, number of variable sites.

*Estimated using the Kimura 2-parameter distance (Kimura 1980).

${ }^{+} P>0.10$, not significant. 
Ciconiiformes (Wenink et al. 1994, Berg et al. 1995) and other vertebrates (Arnason et al. 1993). Although the classification of the Order Ciconiiformes has changed in recent years (Sibley and Ahlquist 1990, Zheng 2002), it was felt that those species mentioned in Wenink's and Berg's studies are closely related to Crested Ibis taxonomically. It is widely accepted that simple sequences with a high AC/GT content are more commonly involved in replication slippages than other sequence motifs (Levinson and Gutman 1987), and both slippage and unequal crossing-over are likely to be involved in the generation of this kind of hyper-variability observed in bird and elephant seal mtDNA (Hoelzel et al. 1993, Berg et al. 1995). Highly conserved B-box and bird similar box were readily recognizable as in most other birds (Ruokonen and Kvist 2002), and the mitochondrial origin of the sequence was confirmed from sequence comparisons with other avian species.

\section{Genetic diversity status}

The distribution of the two haplotypes was not significantly different between the two populations, although the captive population had a bias towards haplotype 1 . The disproportionate haplotype distribution in the captive population is presumably linked to the haplotype composition of the founder population, the difference between individual reproductive capability, and human interference in captive breeding. This imbalance of the haplotype distribution in the captive population might be the first sign of genetic changes occurring in captivity.

Overall, the genetic diversity of Crested Ibis was extremely low compared with other avian species that have experienced population bottlenecks (Glenn et al. 1999, Pestano et al. 2000). This is largely due to the extremely small founder population, of two breeding pairs rediscovered in Yangxian in 1981 and possibly a small number of additional undiscovered birds. Therefore it is the effect of such a small base of genetic diversity within the small founder population, together with the rapid inbreeding that is an inevitable consequence of such a small population size, which has resulted in the current situation of extreme lack of genetic diversity of Crested Ibis.

Population bottlenecks do not necessarily doom a species to immediate extinction, but the loss of genetic diversity is likely to make it more prone to extinction from new diseases or other environmental changes (Frankham et al. 2002). Despite the great success of captive breeding and the increase in individual numbers under intensive management, it is still too early to generalize that Crested Ibis has "recovered" from the threat of extinction. The paucity of genetic variation observed in this study remains a real threat to the environmental adaptation of this species. Therefore, genetic diversity in the Crested Ibis is a major concern in the current conservation of this rare bird.

\section{Conservation implications}

The genetic data presented here have several possible implications for the practical management of Crested Ibis. The mtDNA control region variations detected could provide significant information additional to the studbook for this species. Since the captive population had a bias towards haplotype 1 , special 
attention should be paid to individuals with haplotype 2 when considering captive breeding management, so that haplotype 2 might not be lost by chance and offspring with a better haplotype distribution could be produced.

A long-term goal for the conservation of many endangered species is to eventually reintroduce individuals into the wild, and this is also being considered for Crested Ibis. Populations with low genetic diversity are poorer at coping with environmental extremes and diseases than populations with higher genetic diversity (Frankham et al. 2002). Because of its origin and low genetic diversity, it is feared that Crested Ibis may not be well adapted to reintroduction into new environments, and its ability to tolerate a wide range of environmental extremes and diseases may be more limited. Therefore even greater care should be taken in considering reintroduction sites for this species. When its former range is being considered for release sites, it should be kept in mind that ibises originating from the Yangxian population may not be well suited for reintroduction to distant locations, e.g. in Russia or Korea, with very different environmental conditions. Thus comparative studies between the current habitat and the candidate reintroduction sites, together with environmental monitoring of the candidate sites before release, would be of great importance to the re-establishment of self-sustaining wild populations of Crested Ibis.

\section{Acknowledgements}

We would like to thank Shaanxi Crested Ibis Breeding Centre for providing all the samples used in this study, and we also thank Dr Xu, Dr Wan and Mr Wood for their valuable comments on the manuscript. This work was supported by a grant from the State Key Basic Research and Development Plan of P. R. China (No. G2000046906) and a special grant for Crested Ibis from the State Forestry Administration, P. R. China.

\section{References}

Arnason, U., Bullberg, A., Johnsson, E. and Ledje, C. (1993) The nucleotide sequence of the mitochondrial DNA molecule of the grey seal, Halichoerus grypus, and a comparison with mitochondrial sequences of other true seal. J. Mol. Evol. 37: 323-330.

Avise, J. C. (1994) Molecular markers, natural history and evolution. New York: Chapman and Hall.

Balakrishnan, C. N., Monfort, S. L., Gaur, A., Singh, L. and Sorenson, M. D. (2003) Phylogeography and conservation genetics of Eld's deer (Cervus eldi). Mol. Ecol. 12: 1-10.

Berg, T., Moum, T. and Johansen, S. (1995) Variable number of simple tandem repeats make bird of the order Ciconiiformes heteroplasmic in their mitochondrial genome. Curr. Genet. 27: 257-262.

Brown, G. G., Gadaleta, G., Pepe, G., Saccone, C. and Sbisa, E. (1986) Structural conservation and variation in the D-loop-containing region of vertebrate mitochondrial DNA. J. Mol. Biol. 192: 503-511.

Ding, C. Q. and Liu, D. P. (2002) Crested Ibis Nipponia nippon. Chinese J. Zool. 37: 84.

Frankham, R., Ballou, J. D. and Briscoe, D. A. (2002) Introduction to conservation genetics. Cambridge: Cambridge University Press.

Glenn, T. C., Stephan, W. and Braun, M. J. (1999) Effects of a population bottleneck on Whooping Crane mitochondrial DNA variation. Conserv. Biol. 13: 1097-1107. 
Grunwald, C., Stabile, J., Waldman, R., Gross, R. and Wirgin, I. (2002) Population genetics of shortnose sturgeon Acipenser brevirostrum based on mitochondrial DNA control region sequences. Mol. Ecol. 11: 1885-1898.

Hoelzel, A. R., Hancock, J. M. and Dover, G. A. (1993) Generation of VNTRs and heteroplasmy by sequence turnover in the mitochondrial control region of two elephant seal species. J. Mol. Evol. 37: 190-197.

Kimura, M. (1980) A simple method for estimating evolutionary rate of base substitution through comparative studies of nucleotide sequence. J. Mol. Evol. 16: 111-120.

Kretzmann, M. B., Gilmartin, W. G., Meyer, A., Zegers, G. P., Fain, S. R., Taylor, B. F. and Costa, D. P. (1997) Low genetic variability in the Hawaiian Monk Seal. Conserv. Biol. 11: $482-490$.

Kumar, S., Tamura, K., Ingrid, B., Jakobsen, I. B. and Nei, M. (2001) MEGA2: Molecular Evolutionary Genetics Analysis software. Tempe, AZ: Arizona State University.

Levinson, G. and Gutman, G. A. (1987) Slipped-strand mispairing: a major mechanism for DNA sequence evolution. Mol. Biol. Evol. 3: 203-221.

Li, F. L. (1991) World's first captive breeding of the Japanese Crested Ibis Nipponia nippon. J. Yamashina Inst. Ornithol. 22: 70-76.

Liu, Y. Z. (1981) Rediscovery of Crested Ibis Nipponia nippon in Qinling Mountain. Chinese J. Zool. 27: 237.

Matthee, C. A. and Robinson, T. J. (1999) Mitochondrial DNA population structure of roan and sable antelope: implications for the translocation and conservation of the species. Mol. Ecol. 8: 227-238.

Pestano, J., Brown, R. P., Rodriguez, F. and Moreno, A. (2000) Mitochondrial DNA control region diversity in the endangered blue chaffinch, Fringilla teydea. Mol. Ecol. 9: 1421-1425.

Rozas, J. and Rozas, R. (1999) DnaSP version 3: an integrated program for molecular population genetics and molecular evolution analysis. Bioinformatics 15: 174-175.

Ruokonen, M. and Kvist, L. (2002) Structure and evolution of the avian mitochondrial control region. Mol. Phylogenet. Evol. 23: 422-432.

Sambrook, J., Fritsh, E. F. and Maniatis, T. (1989) Molecular cloning: a laboratory manual. Second edition. New York: Cold Spring Harbor Laboratory Press.

Sibley, C. G. and Ahlquist, J. E. (1990) Phylogeny and classification of birds. New Haven: Yale University Press.

Sorenson, M. D., Ast, J.C., Dimcheff, D. E., Yuri, T. and Mindell, D. P. (1999) Primers for a PCR-based approach to mitochondrial genome sequencing in birds and other vertebrates. Mol. Phylogenet. Evol. 12: 105-114.

Sunnucks, P. (2000) Efficient genetic markers for population biology. Trends Ecol. Evol. 15: 199-203.

Tajima, F. (1989) Statistical method for testing the neutral mutation hypothesis by DNA polymorphism. Genetics 123: 585-595.

Thompson, J. D., Gibson, T. J., Plewniak, F., Jeanmougin, F. and Higgins, D. G. (1997) The Clustal $\mathrm{X}$ windows interface: flexible strategies for multiple sequence alignment aided by quality analysis tools. Nucleic Acids Res. 25: 4876-4882.

Vrijenhoek, R. C. (1998) Conservation genetics of fresh water fish. J. Fish. Biol. 53: 394-412. Wang, S. (1998) China Red Data Book of Endangered Animals: Aves. Beijing: Science Press.

Wenink, P. W., Baker, A. J. and Tilanus, M. G. J. (1994) Mitochondrial control region sequences in two shorebird species, the Turnstone and the Dunlin, and their utility in population genetic studies. Mol. Biol. Evol. 11: 22-31.

Xi, Y. M. and Fujihara, N. (2000a) Prospective future of Crested Ibis. Jpn. J. Zool. Wildlife Med. 5: 115-122.

Xi, Y. M. and Fujihara, N. (200ob) Conservation of Crested Ibis. J. Hum. Anim. Rel. 5: $118-126$. 
Xi, Y. M., Lu, B. Z. and Fujihara, N. (2001) Captive rearing and breeding of the Crested Ibis, Nipponia nippon. J. Poultry Sci. 38: 213-224.

Xi, Y. M., Lu, B. Z., Zhang, Y. M. and Fujihara, N. (2002) Restoration of the Crested Ibis, Nipponia nippon. J. Appl. Anim. Res. 22: 193-200.

Yamashina, Y. (1975) The feeding of Japanese Crested Ibis. Pp. 161-164 in S.A. Temple, ed. Endangered birds. Madison: University of Wisconsin Press.

Yamashina, Y. and Nakanishi, G. (1983) Toki, Nipponia nippon. Tokyo: Newton Books.

Zheng, G. M. (2002) A checklist on the classification and distribution of the birds of the world. Beijing: Science Press.

BEI ZHANG, SHENG-GUO FANG* and YONG-MEI XI

College of Life Sciences, Zhejiang University, Hangzhou, P. R. China

State Conservation Centre for Gene Resources of Endangered Wildlife, and Key Laboratory of Conservation Genetics and Reproductive Biology for Endangered Wild Animals of the Ministry of Education, Hangzhou, P. R. China

*Author for correspondence. Room 418, College of Life Sciences, Zhejiang University, No. 268 Kaixuan Road, Hangzhou, 310029, Zhejiang, P. R. China. e-mail: sgfang@mail.hz.zj.cn

Received 16 May 2003; revision accepted 10 March 2004 